\title{
Network technologies as innovative solution in commodity circulation
}

\author{
I.A. Krasyuk ${ }^{1, *}$, T.V. Kirillova ${ }^{1}$, and N.A. Kozlova ${ }^{1}$ \\ ${ }^{1}$ Saint Petersburg Polytechnic University Peter the Great, 195251 Saint-Petersburg, Russia
}

\begin{abstract}
The paper identifies the specific features of innovations in the trade industry. Innovations, created in other industries, are preferably used in the area of trade. The types of innovations in the field of trade have been specified. The establishment of a networking commercial enterprise has been defined as an innovative solution, widely used in Russian and world practice. The current state of network trade has been investigated and the tendency of retail network expanding in the Russian Federation has been discovered. The concept of a multi-format establishment and the most perspective trade formats have been identified based on the example trading company X5 RetailGroup.
\end{abstract}

\section{Introduction}

Retail trade is a promising area for innovations and effective combinations of various internal and external factors. The innovative approach allows to adapt the activities of trade organizations to market demands and compete with other participants. A distinctive feature of the trade industry is the continuous and systematic implementation of innovations in activity of the industry. Innovations have successfully passed the commercialization, are viable and affect all areas of the commercial enterprise. Innovations in the field of trade include not only modern technologies but also innovations related to marketing, organizational and managerial aspects of the enterprise, with the development of its infrastructure, social sphere and ecology. Despite the fact that a significant share of innovations in trade have been created in other industries, they are also widely used particularly in the trading enterprises.

\section{Topicality of the research}

In the current reality innovations act as a necessary condition for the state economy development as they are aimed at creating new products and new markets. The introduction of innovative solutions contributes to the overall level of economic development, helps to change food processing technologies and improve the means of delivery of goods, provides the intensification of production and technological processes, promotion of goods and services. The sphere of commodity circulation, which is responsible for delivering goods from the production to the final consumer, plays a vital role in modern society. It is rather essential to enhance the innovation potential for further development of trade industry. Innovations improve the efficiency of trade and technological processes, in particular, they have an impact on pricing, help to reduce distribution costs and improve the quality of customer service.

\section{The problem and hypothesis of the study}

The issue that stands in the centre of this study is to determine the prospects of development of retail trade networks as an innovation typical for the modern state of the sphere of commodity circulation. The hypothesis of the study, formulated according to the advanced research problem consists in the fact that the innovation potential of multi-format retail chain affects a wide range of factors, the identification and registration of which contributes to the optimal size of the sales network, as well as the definition of a rational correlation of enterprises of different retail formats included in particular sales network.

\section{The theoretical part}

A wide variety of innovations in the field of commodity circulation requires the classification. Innovations in trade can be divided into several types.

Table 1. Types of innovations in trade [complied by the authors].

\begin{tabular}{|c|l|l|}
\hline $\begin{array}{c}\text { Type of } \\
\text { innovations }\end{array}$ & \multicolumn{1}{|c|}{ Description } & \multicolumn{1}{c|}{ Example } \\
\hline Technological & $\begin{array}{l}\text { Changes in the sphere } \\
\text { of trade and } \\
\text { technological } \\
\text { processes, trade and } \\
\text { technological }\end{array}$ & $\begin{array}{l}\text { The use of the } \\
\text { Internet, the } \\
\text { application of new } \\
\text { refrigerants }\end{array}$ \\
\hline
\end{tabular}

* Corresponding author: iri-krasjuk@yandex.ru 


\begin{tabular}{|c|c|c|}
\hline & $\begin{array}{l}\text { equipment, exchange } \\
\text { of information }\end{array}$ & \\
\hline Social & $\begin{array}{l}\text { Changes in trading } \\
\text { technologies in order to } \\
\text { preserve and } \\
\text { strengthen the buying } \\
\text { habits }\end{array}$ & $\begin{array}{l}\text { Trade enterprises } \\
\text { with non-stop 24- } \\
\text { hours operation; } \\
\text { launch of own } \\
\text { production }\end{array}$ \\
\hline Technical & $\begin{array}{l}\text { Define market } \\
\text { leadership and reduce } \\
\text { distribution costs }\end{array}$ & $\begin{array}{l}\text { Display of goods in } \\
\text { a trading hall in } \\
\text { partitionig } \\
\text { packaging of } \\
\text { manufacturers; } \\
\text { self-checkouts }\end{array}$ \\
\hline Processing & $\begin{array}{l}\text { Design of new } \\
\text { organizational } \\
\text { structures, both within } \\
\text { the firm and inter-firm } \\
\text { level }\end{array}$ & $\begin{array}{l}\text { Multi-format retail } \\
\text { network «X5 } \\
\text { RetailGroup» } \\
\text { includes } \\
\text { hypermarkets, } \\
\text { supermarkets, } \\
\text { discounters and } \\
\text { "convenience } \\
\text { stores". }\end{array}$ \\
\hline Marketing & $\begin{array}{l}\text { Development of } \\
\text { private label brands of } \\
\text { retail chains }\end{array}$ & $\begin{array}{l}\text { Private labels } \\
\text { "Metro", "Dixie", } \\
\text { "Red price" }\end{array}$ \\
\hline
\end{tabular}

Such process innovation as the creation of a retail trade network is on focus of particular interest. This process intensified in the last few decades due to the concentration of trading capital [1].

The use of network technologies in trade is based on the application of various tools, one of which is the modern information technologies, including the Internet opportunities. Information communication in modern trade includes firstly a database of information between buyers and trading company (for the formation of the product range); secondly- communication at the divisional level and management (to increase turnover and operating profit), and thirdly, interacting with suppliers of goods and products. Thus, network ties are formed both in the internal environment of the enterprise and the external contour interaction and, therefore, they become the basis of global activities of the trade industry.

Networking takes various organizational forms, including the forms of vertical inter-firm interactions (cooperation), and the development of horizontal linkages. Network organizational structures have become a natural stage in the evolution of organizational forms and optimally tuned to meet the requirements of modern markets. [2] The economists believe that the network form of business organization while expanding the company's business operate more profitably due to saving internal costs and the small scale of a particular network enterprise allows to adapt to the market demands dynamically. [8]

Achrol R. distinguishes four forms of network interaction. [3]

1. Internal market networks. In such a network the various functional departments of the same organization, endowed with relative autonomy, operate with other internal departments and external agents; satisfy their needs based on market conditions, but act on the basis of the general policy and principles adopted in the organization.
2. Vertical market networks are located around a manufacturing company and represent the channel of supply and distribution.

3. Intermarket networks are grouped around a single major financial structure, or on the basis of intermediary trade firm or manufacturing company.

4. Opportunity networks are the temporary structures created for a particular purpose. In the center of the structure there is, as a rule, the marketing organization. Such networks specialize in gathering market information and provide this information to all the network agents.

In accordance with presented classification, the retail chains are a mixture of all forms of networking. However, a dominant position can be taken by one of the following forms of networks interaction under the particular circumstances.

\section{Applied aspect of research}

The outspread of network trade in the Russian Federation is confirmed by the data presented in table 2 .

Table 2. The share of retail trade networks in formation of retail trade turnover of federal subjcts of the Russian Federation in 2010-2015 years. ${ }^{\text {a }}$

\begin{tabular}{|c|c|c|c|c|c|c|}
\hline $\begin{array}{c}\text { Federal } \\
\text { subject of } \\
\text { RF }\end{array}$ & \multicolumn{5}{|c|}{$\begin{array}{c}\text { The share of retail chains in the total } \\
\text { turnover, in current prices, \% }\end{array}$} \\
\cline { 2 - 7 } & 2010 & 2011 & 2012 & 2013 & 2014 & 2015 \\
\hline CFD & 20,7 & 20,8 & 21,2 & 23,2 & 23,8 & 26,3 \\
\hline Moscow & 19,6 & 18,7 & 19,1 & 20,4 & 20,4 & 21,8 \\
\hline N-WFD & 32,2 & 34,0 & 37,6 & 36,9 & 39,1 & 41,5 \\
\hline $\begin{array}{c}\text { Saint- } \\
\text { Petersburg }\end{array}$ & 48,8 & 51,1 & 53,7 & 49,3 & 52,1 & 52,8 \\
\hline SFD & 15,7 & 17,9 & 20,0 & 20,9 & 22,1 & 23,8 \\
\hline N-CFD & 5,0 & 5,8 & 6,3 & 6,2 & 5,8 & 5,8 \\
\hline PFD & 14,8 & 16,8 & 18,8 & 20,5 & 22,3 & 23,4 \\
\hline UFD & 12,1 & 13,6 & 17,7 & 19,2 & 21,3 & 24,8 \\
\hline SFD & 14,7 & 14,9 & 20,7 & 22,4 & 23,2 & 25,7 \\
\hline FEFD & 7,7 & 7,6 & 9,0 & 9,8 & 10,8 & 11,5 \\
\hline CRFD & - & - & - & - & 4,2 & 20,2 \\
\hline
\end{tabular}

The trend of annual increasing of the share of retail chains in total turnover of trade has been found out in the Russian Federation recently. The reasons are the following: the increasing the profitability of network trade for retailers and the attractiveness of the network for consumers. In the future we can predict either the immutability of the current trend, or maintaining the current share of trade network in the regions of the country.

One of the process innovations used by retail chains is multi-format, which appears as the result of diversification of trade formats aimed at a specific group of customers, unified pricing, trading and technological processes. The purposes of multi-format trade at the level of the trade network are the following:

- different formats specialization;

- maximum coverage of a diverse customer audience;

- bet on the ratio of price and quality. [4]

\footnotetext{
${ }^{a}$ The state statistics Committee of the Russian Federation
} 
Large operators are developing such trade formats like hypermarkets, discounters, supermarkets and "convenience stores". [5]

Table 3. Shares of retail trade formats in the Russian Federation in 2007-2014 years. [6]

\begin{tabular}{|l|c|c|c|c|c|}
\hline $\begin{array}{c}\text { Retail trade } \\
\text { formats }\end{array}$ & $\mathbf{2 0 0 6}$ & $\mathbf{2 0 0 7}$ & $\mathbf{2 0 0 8}$ & $\mathbf{2 0 1 1}$ & $\mathbf{2 0 1 4}$ \\
\hline Hypermarkets & $14 \%$ & $20 \%$ & $28 \%$ & $32 \%$ & $28 \%$ \\
\hline Supermarkets & $40 \%$ & $35 \%$ & $30 \%$ & $12 \%$ & $17 \%$ \\
\hline Discounters & $31 \%$ & $30 \%$ & $27 \%$ & $32 \%$ & $33 \%$ \\
\hline $\begin{array}{l}\text { "Convenience } \\
\text { stores" }\end{array}$ & $4 \%$ & $6 \%$ & $8 \%$ & $14 \%$ & $12 \%$ \\
\hline Others & $11 \%$ & $9 \%$ & $7 \%$ & $10 \%$ & $10 \%$ \\
\hline
\end{tabular}

According to Table 3, the most common formats of trade in the Russian Federation are hypermarkets and supermarkets. The country's largest trading company X5 RetailGroup includes commercial properties of different sizes (Table 4.).

Table 4. Dynamics of the number of retail properties belonging to X5 RetailGroup trading company for 2007-2016., items.

\begin{tabular}{|c|c|c|c|c|c|}
\hline $\begin{array}{c}\text { Retail trade } \\
\text { formats }\end{array}$ & $\mathbf{2 0 0 7}$ & $\mathbf{2 0 1 0}$ & $\mathbf{2 0 1 2}$ & $\mathbf{2 0 1 6}$ & $\begin{array}{c}\mathbf{2 0 1 6 . ~ K} \\
\mathbf{2 0 1 3} \mathbf{\%}\end{array}$ \\
\hline Discounters & 674 & 1999 & 3220 & 8363 & 259,7 \\
\hline Supermarkets & 179 & 310 & 370 & 539 & 145,7 \\
\hline Hypermarkets & 15 & 71 & 78 & 91 & 116,7 \\
\hline $\begin{array}{c}\text { "Convenience } \\
\text { stores" }\end{array}$ & - & 45 & 134 & 194 & 144,8 \\
\hline Total & 868 & 2425 & 3802 & 9187 & 241,6 \\
\hline
\end{tabular}

The discounters are developing the most rapidly. It should be noted that in this trading network the format of a hypermarket has not received proper development. Recently, the company has actively used the tool of franchising, including franchise back. [7]

\section{Conclusions}

Retail trade is a promising field for the introduction of different kinds of innovations. The complexity and uniqueness of the retail chains, as well as the prospects for their development determine the variety of innovations applied. Trade network is the process innovation in the field of commodity circulation and is defined as a trading enterprise with a single point of management, coordination and control, centralized supply system, a unified development strategy (product range, pricing, advertising), operates under a single brand.

The multi-format trade network is the kind of process innovation, which combines a variety of formats in a single trading network. Other innovations in trade are associated with technological, technical, social, marketing and other aspects.

\section{References}

1. T.V. Kirillova, Practical Marketing, 2-1(240-1), 2230 (2017)

2. M.A. Beck, N.N. Beck, E.V. Buzulukova, The methodology of the study of network forms of business organization: monograph (Publishing house of the Higher school of Economics, Moscow, 2014)

3. R.S. Achrol, Journal of the Academy of Marketing Science, 25, 1, 56-71 (1997)

4. Z.V. Kotelnikov, Development of retail networks as a backbone element of the transformation of the trade (for example, food sector). Organizational forms and competitive strategies in the Russian retail trade (regional aspect) (Vershina, Moscow, 2008)

5. D.A. Popov, V.A. Sinyukov, Formats of retail: evolution and modernity: monograph (RICHIEP, Khabarovsk, 2013)

6. www.planet.retail.net

7. V.P. Cheglov, Innovative retail companies. Organizational leadership and effective technology: monograph (Publishing house FORUM, Moscow, 2014)

8. I.A. Dudakova, Marketing solutions network technologies in the retail trade: monograph (Publishing house Dashkov and K, Moscow, 2007) 